\title{
Legal Interventions and Transnational Alliances in the Ali Enterprises Case: Struggles for Workers' Rights in Global Supply Chains
}

\author{
Miriam Saage-Maaß
}

\begin{abstract}
This article highlights the persistence of exploitative working conditions in global supply chains resulting from the constant need to externalise costs and increase consumption with a view to sustaining the "imperial lifestyle" of people in the Global North. While the law structures today's global value chains and is designed to secure the economic interests of Global North companies that sit the top of most of such chains, it also bears considerable potential for transformation and empowerment. The different legal interventions around the 2012 Ali Enterprises factory fire demonstrate that law is not only a direct product of dominant class interests, but that it can also open up opportunities for resistance and emancipatory struggle. Written from the perspective of one of the actors closely involved in the legal struggle for justice that followed the Ali Enterprises factory fire, both in terms of building transnational alliances as well as in the litigation itself, this chapter critically reflects on the achievements of the legal interventions carried out and also attempts to develop criteria for a holistic approach to what is often called strategic litigation.
\end{abstract}

Keywords Global value chains · Strategic litigation · Movement lawyering · Marxist critiques of law $\cdot$ Decolonial critiques of law $\cdot$ Transnational law $\cdot$ Human rights $\cdot$ Labour rights $\cdot$ Tort law litigation

I want to thank Corina Ajder, Johan Horst, Wolfgang Kaleck, Cannelle Lavite, Franziska Oehm, Christian Schliemann, Faisal Sidiqqi, Palvasha Shahab, Ben Vanpeperstraete and, last but absolutely certainly not least, Michael Bader, for their helpful comments on the text, but also more generally for the many opportunities for discussion and reflection. I also want to thank Carolijn Terwindt who accompanied me on the case for a long time. Her insights are surely also reflected in this text.

M. Saage-Maaß $(\bowtie)$

European Center for Constitutional and Human Rights, Berlin, Germany

e-mail: saage-maasz@ecchr.eu 


\section{Introduction}

Human rights litigators and activists around the world often use law and legal proceedings to challenge those in positions of power, whether they be governments or corporate actors, involved in human rights abuses. Using law as a defence against state and corporate oppression is not a recent phenomenon; the anti-slavery movement, the nineteenth and early twentieth-century workers' movement, as well as the women's movement have all used law and litigation as a tool to fight for social change. In a time of globalised neoliberal market economies, communities and individuals have now started to use litigation against multinational corporations as a way to address the many harms they cause. This trend is often called transnational strategic litigation, as it seeks to hold parent companies liable in the jurisdictions in which they are headquartered for violations that have occurred in foreign states, often through the involvement of company subsidiaries. The first lawsuits of this kind were filed in the USA under the Alien Tort Statute (ATS), for example, against British-Dutch oil company Shell for its involvement in the killing of Nigerian activist and writer Ken Saro Wiwa and others in 1996. Also, in the mid-1990s, South African workers started to sue British parent companies in English courts, claiming compensation for occupational health damages like asbestosis. ${ }^{1}$

The strategy of using transnational litigation to address human rights abuses caused by multinational corporations has been picked up by different groups of affected people and rights advocates around the world, using not only civil law, but also other legal claims and procedures. ${ }^{2}$ Still, in 2012, when the Ali Enterprises factory fire killed 258 workers and injured tens of others, litigation of this kind was mainly concentrated on challenging corporate involvement in parent-subsidiary relationships and-at least in the US-in grave international crimes like torture, killings, or slave labour. ${ }^{3}$ Hardly any lawyers considered challenging supply-chain relationships through litigation as it already seemed hard enough to argue that parent companies bear responsibility for harm caused or contributed to by their foreign subsidiaries. Also, for labour activists, the idea that one might not only use national labour courts to address factory owners' responsibilities, but also to legally challenge the multinational brands buying from these factories, was novel.

This chapter will describe the 2012 Ali Enterprises incident and the related legal interventions that evolved in its wake, contextualising them within the realities of capitalist production in global value chains and law's particular role in securing the profits and interests of transnational business. Coming from a critical legal perspective, it recognises law's many shortcomings and pitfalls, but also its emancipatory

\footnotetext{
${ }^{1}$ Meeran (2011).

${ }^{2}$ For an overview, visit the "legal accountability" section of the Business and Human Rights Resource Centre website: www.business-humanrights.org/en/big-issues/corporate-legal-account ability/ (last accessed 12 September 2020).

${ }^{3}$ This case selection was, and to some extent still is, primarily driven by the legal requirements of the respective causes of action, as the ATS, in particular, requires a violation of the "law of nations."
} 
potential. Indeed, the chapter explores this ambiguity of law by highlighting how affected groups and those supporting their struggle were able to use the legal interventions around the Ali Enterprises incident in a self-empowering way. While legal actions often aim to set legal precedent, there are potential effects beyond the courtroom. This chapter shows that those driving the litigation can intervene in public and legal discourses, and thereby influence the way exploitation and "organised irresponsibility" are created in global value chains. While it is impossible to say that a few legal actions will fundamentally change the daily realities of workers in global value chains, they can and do contribute to broader trajectories of emancipatory change.

\section{The Context of the Ali Enterprises Factory Fire Litigation}

The litigation against the German company KiK Textil und Non-Food GmbH (KiK) and the Italian firm RINA SpA cannot be fully understood if only viewed as single, isolated instances of transnational strategic litigation. Instead, these legal proceedings should be considered in the context of the broader economic realities of globalised value chains, which are structured according to law. ${ }^{4}$ In this context, the legal system plays the role, first and foremost, of protecting business interests and sustaining the Global North's imperial way of life. At the same time, however, the legal system also holds out fora through which the very same system can be challenged.

\subsection{The South Asian Textile Industry and Europe's Enduring Imperial Way of Life}

The textile industry is paradigmatic of the current neoliberal, globalised economy in that it is based on the continuous exploitation of natural resources and labour. ${ }^{5}$ This starts with the agricultural production of cotton, which has major impacts on the environment as well as humans. Described as the birthplace of global capitalism, the cotton industry was a key historical driver of colonialism and the slave trade. ${ }^{6}$ Today, it is one of the major drivers behind the growing need for pesticides, with all of their devastating consequences for nature, the climate, and people. ${ }^{7}$ The cycle

\footnotetext{
${ }^{4}$ Scholars have rightly pointed out the need to understand the law of global value chains as a field in itself that transcends the classic disciplinary boundaries of law, just as value chains transcend national borders. Baars et al. (2016).

${ }^{5}$ Lehmann (2012).

${ }^{6}$ Beckert (2014), pp. $98 \mathrm{ff}$.

${ }^{7}$ Orsenna (2007) and Kumar (2015).
} 
of exploitation continues with cotton processing: from bad working conditions in ginning mills, to dyeing departments where all kinds of hazardous chemicals are used, and on to the actual factories producing ready-made garments for the global market. ${ }^{8}$

Within this production chain, described here only superficially, it is clear that textile factories producing for the international market are not the worst places to work. As industrial workplaces that provide more or less regular salaries, they are relatively less precarious than agricultural or home-based work. Especially in Bangladesh, jobs in garment factories offer an opportunity for young women to have an income independent from their families. But studies have shown that despite the majority of workers being women, gender discrimination is endemic on the factory floor. Hence, to praise such jobs as providing an opportunity for women's emancipation would mean only telling half of the story. ${ }^{9}$

The Ali Enterprises fire was followed by two other factory accidents in Bangladesh: the Tazreen Fashions fire in November 2012, which killed around 100 workers, and the Rana Plaza building collapse in April 2020, which left over 1000 workers dead and even more seriously injured for life. ${ }^{10}$ Of course, prior to these incidents, labour rights groups like the Clean Clothes Campaign had been warning about fire and building safety risks in the industry for many years. ${ }^{11}$ And still, bad fire and building safety conditions are only one of many symptoms of the exploitative nature of globalised production chains in the textile industry. Wages below the minimum needed to live, excessive overtime, a lack of social benefits, systematic repression of workplace organising and unionisation, as well as gender discrimination and gender-based harassment are the daily realities for many workers in globalised value chains. ${ }^{12}$ Although these issues were much discussed by workers' rights groups before the 2012-2013 spate of factory disasters in South Asia, they had been largely ignored by the majority of consumers in the Global North. The three disasters were so emblematic of the industry's systemic problems, however, that they made it impossible for a larger public in Europe and North America to continue to avoid the fact that workers in South Asia and elsewhere risk their lives to produce their clothes.

\footnotetext{
${ }^{8}$ Orsenna (2007).

${ }^{9}$ Hossain (2012). Interestingly, weavers in the cotton mills of nineteenth century Britain were also predominantly women and child labour was common. Beckert (2014), pp. 188 f., $191 \mathrm{f}$.

${ }^{10}$ Clean Clothes Campaign, Rana Plaza, www.cleanclothes.org/campaigns/past/rana-plaza (last accessed 12 September 2020).

${ }^{11}$ Clean Clothes Campaign (2005).

${ }^{12}$ Anner (2020); Clean Clothes Campaign, Pakistan. Country Report, 2015.
} 


\subsection{The Law of Global Value Chains}

The key feature of our current economic system is the externalisation of costs. ${ }^{13}$ Over the last 30 years, the predominant model of the hierarchically structured company with an almost entirely integrated value chain (from the iron mine to the finished automobile), has been replaced by the production model of value chains that arose in the 1980s. ${ }^{14}$ Legal obligations to respect labour rights and environmental legislation present as "costs" in this production-model logic, and the law of globalised value chains organises the outsourcing of these costs. On the one hand, international trade law ensures that transnational companies can extract their profits and maintain access to markets and resources. On the other hand, responsibility is reduced and diffused, especially through commercial and company law.

\subsubsection{International Trade Law}

At the macro level, free trade and liberalisation policies are realised through the international treaty provisions of the World Trade Organization and, increasingly, through regional or bilateral free trade agreements. The reduction and removal of tariffs and trade quotas in the mid-1990s was the determining factor for the rapid increase in textile production that occurred in countries like Bangladesh, India and China. While this enabled these countries to even more grow export-oriented textile industries, it also enabled the EU and US to increasingly outsource their production in order to cut production costs. In this regard, international trade agreements have enabled the access of international buyers to both foreign production sights as well as foreign markets in which to sell their goods. At the same time, a set of laws that includes international investment treaties, intellectual property laws, and international finance regulation, ensures that resources and profits are protected and can be extracted from these foreign markets. ${ }^{15}$ This body of international economic law has robust and effective enforcement mechanisms, such as the much criticised arbitration procedures for alleged violations of bilateral investment treaties or patent rights. ${ }^{16}$ These laws and arbitration procedures primarily protect the needs of transnational companies for structured trade processes and extensive profit accumulation, while employee and environmental concerns are neglected and even framed as illegal infringements on legitimate property rights. Different authors have shown that this role of international economic law-in enabling access to human labour and natural resources while at the same time protecting the extraction of profits-is a

\footnotetext{
${ }^{13}$ Brand and Wissen (2017), pp. 30 ff., 63 f.; Lessenich (2018).

${ }^{14}$ Gereffi et al. (2005), pp. 78 ff.; Barrientos et al. (2016), pp. 1214-1219.

${ }^{15}$ Horst (2015), Mgbeoji (2006) and Rahmatian (2009).

${ }^{16}$ An overview can be found at: Kaleck and Saage-Maaß (2016), pp. 49 ff.
} 
continuation of the racist, colonial origins and traditions of international law more broadly. $^{17}$

\subsubsection{Commercial and Company Law}

While neoliberal thinkers generally claim to advocate for deregulation and the reduction of legal provisions, neoliberal production via global value chains is entirely structured and enabled through law. ${ }^{18}$ The law, usually commercial law, organises business practices and, in particular, secures the economic interests of the powerful actors at the top of complex value chains.

Companies organise the global expansion of their activities through the establishment of subsidiaries and a complex system of supply relationships. ${ }^{19}$ It is not uncommon today for corporations to have several hundred subsidiaries and even more suppliers. Anything from 100\% ownership of subsidiaries to the participation of several other companies and financial investors is an option.

The externalisation of liability risks within a corporate group is primarily achieved through the dogmatic figure of the so-called separation principle, i.e. limited liability. ${ }^{20}$ This company law concept exists in almost all legal systems across the globe and establishes that the subsidiaries in a corporate group are to be regarded as legal entities separate from and completely independent of the parent company. ${ }^{21}$ This limitation of legal responsibility within the corporate group creates what can be best described as "organised irresponsibility," as local producers often cannot be held to account for harms caused due to practical reasons, while the corporations that hold shares in or exercise a position of economic dominance over the local producing company are, legally, not responsible. In reality, this is often legal fiction. Although an individual group's subsidiaries are, from a legal point of view, independent and not bound by instructions of the group's top management, actual corporate governance structures often entail tight, hierarchical organisation. They also frequently include supervisory and directive powers for the group's board of directors with regard to the group's subsidiaries.

According to the World Bank, roughly $80 \%$ of global production is created in supply chains. ${ }^{22}$ In this context, another legal fiction becomes relevant, as both

\footnotetext{
${ }^{17}$ Chimni (2013), pp. 251 ff.; Anghie (2004) shows that investment treaties were closed in the moment that the former colonies gained sovereignty of their resources.

${ }^{18}$ Britton-Purdy et al. (2020). On the particular role of lawyers in this, see Pistor (2019).

${ }^{19}$ For a definition and distinction between supply chains and supplier networks, see Plank et al. (2009).

${ }^{20}$ Baars (2019).

${ }^{21}$ A comprehensive description of the problem can be found in Wagner (2016), pp. $717 \mathrm{ff}$.

22،"Global investment and trade are inextricably intertwined through the international production networks of firms investing in productive assets worldwide and trading inputs and outputs in crossborder value chains of various degrees of complexity. Such value chains (intra-firm or inter-firm, regional or global in nature, and commonly referred to as Global Value Chains or GVCs) shaped by
} 
national and international contract law are based on the principle of "equality of the contractual partners." 23 Contractual supply relationships are realised though diverse legal constellations. From long-term business relationships with the manufacturers of highly specialised and technically sophisticated products to volatile order placement via auction platforms, many variants, and also a combination of different supplier relationships, is conceivable. ${ }^{24}$ As the organisational set-up of value chains is mainly driven by the goal of cost reduction and profit maximisation, workers' rights to appropriate remuneration, social security, and environmental protection are cost factors left up to the supplier. As a result, neglecting regulations that protect the interests of the common good turns out to be a favourable cost factor in the contractual relationship between local producers and transnational corporations. The interests of employees or communities negatively affected in the process of production would only function as cost-raising factors and have no legal relevance in the contractual relationship. ${ }^{25}$

A recent example of the great social and economic inequality between formally equal contracting parties in global supply chains in the textile industry could be seen when consumer demand dropped drastically due to Covid-19 lockdowns in March and April 2020, and international buyers unilaterally cancelled orders and refused to even pay for already produced goods. ${ }^{26}$ Often, these cancellations were not even backed by the international buyers' own contracts, let alone force majeure provisions in national or international contract law. ${ }^{27}$ Still, international buyers were able to cancel the orders because they knew their suppliers would hardly object, being in desperate need for the next order once the crisis subsides. As a result, millions of workers in Asia lost their jobs within weeks and were left without savings or social protection schemes. Even if factory owners would have wanted to do otherwise, they work on such tight margins that they were unable to pay workers once the international brands and retailers refused to pay for the already-produced goods. ${ }^{28}$ While international buyers make significant profit, they leave so little to their producers and their workers that any friction in market demand leads to social disaster.

\footnotetext{
TNCs [transnational corporations] account for some $80 \%$ of global trade." UNCTAD, World Investment Report (2013), www.unctad.org/en/PublicationsLibrary/wir2013_en.pdf (last accessed 12 September 2020).

${ }^{23}$ Gathii and Odumosu-Ayanu (2015), pp. $70 \mathrm{f}$.

${ }^{24}$ Gereffi (2005), pp. $1 \mathrm{ff}$.

${ }^{25}$ Gathii and Odumosu-Ayanu (2015) and Britton-Purdy et al. (2020).

${ }^{26}$ Nova and Zeldenrust (2020); Lane M, 150,000 have lost jobs in Cambodia garment sector. Apparel Insider, 30 June 2020, www.apparelinsider.com/150000-have-lost-jobs-in-cambodiagarment-sector/ (last accessed 12 September 2020); Garment exporter Bangladesh faces $\$ 6$ billion hit as top retailers cancel. Reuters, 31 March 2020, www.reuters.com/article/health-coronavirusbangladesh-exports/garment-exporter-bangladesh-faces-6-billion-hit-as-top-retailers-cancelidUKKBN21I2R9 (last accessed 12 September 2020).

${ }^{27}$ Vogt et al. (2020).

${ }^{28}$ Anner (2020).
} 


\subsection{Critical Perspectives on the Law}

Law's function in engineering global value chains in the interest of multinational companies and economic elites has been identified as a typical characteristic of law in general and, more specifically, has been the subject of Marxist critiques of law for quite a long time. According to Otto Kirchheimer, for instance, law is a "guarantee of the existing social order." 29 In a similar vein, Franz Neumann asserts that law corresponds with the interests of the ruling classes and the bourgeois way of life, as it safeguards property and private autonomy, and, above all, ensures the calculability of commodity production and trade. ${ }^{30}$ Critical legal studies scholars have shown that law disguises exactly these power dynamics, as it creates a notion of neutrality and gives the impression that the existing order is both just and fair. ${ }^{31} \mathrm{~A}$ wide range of authors have also identified the abstract legal subject as problematic. ${ }^{32}$ Judith Butler, for example, points out that the limitation of the language of law forces us to describe the abuse of power as a violation of rights, which means that a rights violation can only be framed as an act attributable to an individual subject. Hence, by focusing on the legal subject, the complex institutional structures leading to abuse and harm are made invisible. ${ }^{33}$ For Christoph Menke, meanwhile, the pitfall of our current legal system lies more fundamentally in the creation of (individual) rights as such. In his assessment "rights" in bourgeois societies are privatised into something pre-political; they are taken away from the community of citizens and given to the individual. ${ }^{34}$

\subsection{Legal Avenues for Those Affected by Human Rights Violations in Global Supply Chains}

One can find support for these critical perspectives on the law in the Ali Enterprises case, in which the neutrality of contract law, the fiction of equality between the contractual parties, and the fiction of separate legal entities disguise the actual power imbalance between the international retailers and brands on one side, and their supplying manufacturers and the actual factory workers on the other. The fact that four people had to bring a claim against $\mathrm{KiK}$ alleging violations of their individual

\footnotetext{
${ }^{29}$ Kirchheimer (1976), p. 78.

${ }^{30}$ Neumann (1980), p. 246.

${ }^{31}$ Kennedy (1997), p. 311; Gabel and Harris (1982-1983), p. 372.

${ }^{32}$ Critics range from such diverse authors as the legal theorist of the Russian Revolution, Eugeny Paschukanis, to post-structuralist scholars like Judith Butler.

${ }^{33}$ Butler (2006), p. 125. For more on how law produces the notion of a subject before the law as a naturalised basic assumption and subsequently conceals this production and, thus, its own regulatory hegemony, see Butler (1991), p. 17.

${ }^{34}$ Menke (2018a).
} 
rights clearly neglects the complex social and economic interdependencies in which these rights violations occurred. More fundamentally, the idea of "property" entailing a private right to subject nature and humans to an exploitive production process can be described as the underlying principle of global value chains.

As law creates the externalisation and fragmentation of responsibility in global value chains, it, in turn, creates serious obstacles for affected persons in terms of demanding respect for their labour and human rights. And still, as the production along supply chains creates relationships between actors, like workers in supplying factories and managers in lead firms or auditing companies, new potential claims for workers and other affected groups arise. In the litigation around the Ali Enterprises case, a range of these options were used.

\subsubsection{Multiple Jurisdictions}

As companies have extended their economic activities across different jurisdictions, affected persons have gained, at least in theory, the ability to take action against the various actors involved in the production process in the different jurisdictions in which they are incorporated. For example, as described by Faisal Siddiqi in this book, complaints about working conditions at a production site can be directed against the actual factory owners, against local authorities responsible for monitoring industrial health and safety standards, or against local certification service providers. Apart from the practical and legal hurdles that workers face in their local legal systems, as Faisal Siddiqi and Palvasha Shahab both describe in their chapters, local courts usually do not have jurisdiction over companies incorporated abroad. Yet, it can also be an option to start legal proceedings in the jurisdiction where the actors along the production process are located. In this case, claims are directed against the parent company of the corporate group, the buying company at the end of the supply chain, or the certification companies located in Europe or North America, as was done in the legal proceedings against KiK in Germany and against RINA in Italy. In these jurisdictions, victims of corporate abuse may choose between civil litigation, to ask for monetary compensation for harm and suffering, and criminal procedures, which will investigate the responsibility of managers and the company as such, and potentially sanction individual corporate managers and the legal entity. ${ }^{35}$ Obviously, all of these legal venues are far from easily accessible for potential claimants in global value chains, but they exist at all and that they also give those exploited in supply chains an option for transnational legal interventions.

In line with the general trend towards more flexible forms of regulation and new instruments of implementation in international as well as national law, there are a

\footnotetext{
${ }^{35}$ Meeran (2011); Kaleck and Saage-Maaß (2010); Tixeire C, Can the Lafarge case be a game changer? French multinational company indicted for international crimes in Syria. Business and Human Rights Centre Blog, www.business-humanrights.org/en/can-the-lafarge-case-be-a-gamechanger-french-multinational-company-indicted-for-international-crimes-in-syria (last accessed 12 September 2020).
} 
number of soft law standards and complaint mechanisms that deal with and define companies' responsibilities for human rights in their global value chains. ${ }^{36}$ The most important soft law standards are the OECD Guidelines for Multinational Enterprises and the UN Guiding Principles on Business and Human Rights (UNGPs). The OECD guidelines are accompanied by a non-judicial complaint mechanism designed to mediate between complainants and the company. As required by the UNGPs, companies are also increasingly setting up their own internal complaint mechanisms. ${ }^{37}$ While the effectiveness of these complaint procedures can be debated, soft law standards and their multiple complaint mechanisms nevertheless extend the range of possible forums that can be used by those affected. ${ }^{38}$

\subsubsection{Expansion of the Legal Doctrines on Parent Company and Supply Chain Liability}

Despite the dogmatic fictions described above that create a lack of responsibility in global production processes, there is increasing academic debate and case law on extending the tort law liability of transnational companies. The starting point of these discussions are cases in which English courts recognised that parent companies can be liable under tort law for damages caused by subsidiaries abroad, when the harm was foreseeable, when there was sufficient proximity between the parties, and when the imposition of a duty could be seen as fair, just, and reasonable. ${ }^{39}$ In the most recent Vedanta decision, the UK Supreme Court even held that public corporate social responsibility (CSR) commitments and company policies are relevant in creating and defining the duties a parent company bears with respect to preventing its subsidiary from causing human rights and environmental harms. ${ }^{40}$ Subsequently, authors have pointed out that, in accordance with the case law on Chandler v. Cape

\footnotetext{
${ }^{36}$ The term soft law includes resolutions of the UN General Assembly, codes of conduct, guidelines, and recommendations of international organisations, but also declarations and final acts of international organisations.

${ }^{37}$ In doing so, they are following a stipulation of the UNGPs, which also call on companies to introduce complaint mechanisms as part of a "smart mix" of state and private regulations. UN Guiding Principles on Business and Human Rights (UN doc A/HRC/17/31).

${ }^{38}$ Krajewski et al. (2016).

${ }^{39}$ Van Dam (2010), pp. 221 ff.; Meeran (2011).

${ }^{40}$ In Vedanta, the UK Supreme Court held, that "the parent may incur the relevant responsibility to third parties if, in published materials, it holds itself out as exercising that degree of supervision and control of its subsidiaries, even if it does not in fact do so. In such circumstances its very omission may constitute the abdication of a responsibility which it has publicly undertaken." The court also held that "everything depends on the extent to which, and the way in which, the parent availed itself of the opportunity to take over, intervene in, control, supervise or advise the management of the relevant operations (including land use) of the subsidiary. All that the existence of a parent subsidiary relationship demonstrates is that the parent had such an opportunity." Vedanta Resources PLC v Lungowe [2019] UKSC20, para. 53 and 49.
} 
plc, Vedanta, and others, certain basic assumptions of company law must also be questioned with regard to supplier companies. ${ }^{41}$

\subsubsection{Liability of Social Auditors}

Social auditing companies belong to the multitude of actors in global value chains. They often replace state-run labour inspections and are a tool for multinational companies to ensure that their codes of conduct on labour rights are adhered to. ${ }^{42}$ Corporate codes of conduct have been the textile industry's reaction to consumer campaigns in North America and Europe scandalising the discrepancy between the shiny image of textile and sports brands in the Global North and the horrifying reality of working conditions in the Global South. ${ }^{43} \mathrm{KiK}$, just like many other brands and retailers in the textile industry, created a code of conduct in which it declares its commitment to labour standards like health and workplace safety. In order to ensure compliance, brands and retailers usually employ social auditing firms that visit local supplier factories to verify that they respect the code of conduct. These audits often fail to accurately describe the situation in factories, however, due both to the methodological restrictions of their approach, as well as to conflicts of interest and corruption. As such, social audits serve the purpose of diffusing responsibility and giving multinational brands and retailers the possibility of pointing to an audit report to claim that they had done everything in their power to avoid the disaster. The auditing company, in turn, can hide behind the technicalities of their mandate, which restricts their assessment and, hence, their responsibility. This mutual fingerpointing further contributes to the system of organised irresponsibility mentioned above. Currently, it is being discussed whether auditors should be liable under criminal or civil law for audit reports that fail to report adequately or truthfully on workplace safety and labour law violations in supplier companies. ${ }^{44}$ In particular, the question has been raised as to whether the concepts of third-party beneficiary rights or other tort law concepts can also be applied to social auditors. ${ }^{45}$

\footnotetext{
${ }^{41}$ Heinen (2018), pp. 96 f.; Heinlein (2018).

${ }^{42}$ As described by Palvasha Shahab in this volume, the international finance institutions' push to systematic privatisation and a slim state has meant that the capacities of labour inspectorates in South Asia have been minimised.

${ }^{43}$ Klein (2005).

${ }^{44}$ Terwindt and Saage-Maß (2017) On the liability of social auditors in the textile industry. Friedrich-Ebert-Stiftung (ed) International Policy Analysis, www.library.fes.de/pdf-files/iez/ 13041.pdf (last accessed 12 September 2020).

${ }^{45}$ Glinski and Rott (2019).
} 


\section{The Ali Enterprises Factory Disaster and the Litigation That Followed}

In the following, I will show how the different legal interventions in the Ali Enterprises case not only exemplify law's shortcomings in protecting the interests of workers in global value chains, but also how they exemplify the various avenues in global supply chains through which workers can demand redress and compensation.

On the evening of 11 September 2012, a fire broke out on the ground floor of the Ali Enterprises factory. ${ }^{46}$ It spread quickly to the other floors and many workers were not able to leave the building quickly enough due to the lack of accessible fire exits and the failure of the factory's fire alarm system. At least 258 workers died in the fire and several dozen more were wounded. The main buyer of the factory was the German retailer KiK. According to the company's own claims, it had been purchasing around $70 \%$ of the factory's production for a period of 5 years.

The German public came to know about the Ali Enterprises fire mainly through an interview published by Der Spiegel with KiK's corporate social responsibility manager. ${ }^{47}$ In the interview, the manager-expressing dismay about the disasterdescribed the relationship between $\mathrm{KiK}$ and Ali Enterprises as close and longlasting. He explained how $\mathrm{KiK}$ was keen to exercise its corporate social responsibility through the creation of a code of conduct for its suppliers, expecting them to respect health and safety regulations and other core labour standards. Compliance with these standards was to be ensured through on-site visits of company representatives and social auditing firms. In the course of the litigation after the fire, KiK also produced four social audit reports that had been commissioned by the company between 2007 and 2011. Only the first one in 2007 had shown any concern regarding fire safety, while the others did not reflect any major insufficiencies. Additionally, just a few weeks before the deadly fire broke out, on 21 August 2012, the Italian auditing firm RINA SpA issued the factory a SA-8000 safety certificate, said to be one of leading social certification standards for factories and organisations worldwide. RINA had been hired by the Ali Enterprises factory owners. Its certification of the factory was preceded by an audit report, which was approved by RINA's technical committee on 3 August 2012. RINA had selected and hired the Pakistani service provider RI\&CA to conduct the audit. After its verification of the audit report, RINA certified the facility. In the aftermath of the Ali Enterprises fire, the SA-8000 scheme-holder, the Social Accountability Initiative, conducted an

\footnotetext{
${ }^{46}$ For a detailed reconstruction of the fire see: Forensic Architecture, The Ali Enterprises Factory Fire, www.forensic-architecture.org/investigation/the-ali-enterprises-factory-fire (last accessed 12 September 2020).

${ }^{47}$ Kazim H and Klawitter N, Zuverlässiger Lieferant. Der Spiegel, 22 October 2012, www.spiegel. de/spiegel/print/d-89234400.html (last accessed on 12 September 2020).
} 
investigation into the incident and concluded that there had been several serious shortcomings and even fraudulent behaviour in the certification process. ${ }^{48}$

\subsection{The Building of Transnational Alliances}

The international labour rights movement's immediate reaction to the Ali Enterprises catastrophe in Pakistan and the two subsequent factory disasters in Bangladesh must be seen in its historic context. Over the last 30 years, the anti-globalisation and consumers' movement has developed into a well-connected network of various trade unions, research and campaigning organisations across Europe, Africa, Asia, and the Americas, with a focus on labour rights in the global textile industry. Over the years, these organisations have cooperated in different constellations on numerous campaigns to scandalise the exploitative labour conditions in textile production, ${ }^{49}$ point out the ineffectiveness of corporate social responsibility measures, ${ }^{50}$ and call for more robust mechanisms to ensure that brands actually contribute to the improvement of working conditions. ${ }^{51}$ The high level of transnational interconnectedness and professionalism already existing between these trade unions and labour organisations in the Global South and Global North allowed them to respond immediately to the major textile industry disasters between September 2012 and April 2013. They quickly mobilised international media attention to the disasters and launched a global campaign demanding international fashion brands and retailers contributein the absence of functioning social protection schemes in Pakistan and Bangladesh - to compensation funds for workers. It was their ability to scandalise and raise attention around the issue which created the unprecedented global outcry and the immense pressure on brands that eventually led to the Accord on Fire and Building Safety in Bangladesh and, later on, to the Rana Plaza Compensation Agreement. $^{52}$

At this point in time, the European Center for Constitutional and Human Rights had already done quite some research and thinking about the legal arguments that one would need to make to hold a European company responsible in court for human rights violations in its supply chain. ${ }^{53}$ While most European and US litigators had

\footnotetext{
${ }^{48}$ Social Accountability International (2013), Report Addendum on Fire Safety in Pakistan, p. 16. workshops with activists and lawyers from South Asia, Western and Southern Africa, and Latin America. As a conclusion, it determined that labour exploitation in global value chains was one of the most pressing human rights issues where European companies played a major role. Lessons learned from this process can be found in Saage-Maaß (2014).
} 
previously concentrated on holding parent companies liable for the human rights violations committed by their foreign subsidiaries, ECCHR had begun, since 2010, to use different legal tools to approach the topic of labour exploitation in global supply chains. This included filing consumer claims alleging that a company's advertisement of its code of conduct constituted misleading advertisement, ${ }^{54}$ and by filing OECD complaints against European cotton trading companies. ${ }^{55}$

After the previously mentioned Spiegel article was published in late September 2012, it was clear that the constellation of facts revealed would potentially allow workers to directly go to court in Germany against the retailer KiK. While the Ali Enterprises incident was extraordinary in its cruelty and devastation, it also displayed several crucial factors for a potential legal claim. There was a clear violation of the right to life and health, which translates into civil law as a tort, and an undeniable connection to both the retailer KiK in Germany and the auditing company RINA in Italy, which is often difficult to establish. As KiK had admitted to being the major buyer of the Ali Enterprises factory, there was also a reasonable indication of control on the part of KiK.

In autumn of 2012, ECCHR learned that its partner organisation medico international (medico) was supporting the National Trade Union Federation (NTUF) in Karachi in its efforts to organise the survivors and families of the deceased from the Ali Enterprises fire. Right away, medico, NTUF and ECCHR started discussing the possibilities for a common legal effort to hold the German brand KiK and the Italian firm RINA to account. Representatives of medico and ECCHR travelled to Karachi for the first time in February 2013, where we held long deliberations with NTUF, the Pakistan Institute of Labour Education and Research (PILER), as well as groups of survivors and family members of the deceased. Over the next 5 years, several trips followed, occurring almost every 6 months. As described by Saeeda Khatoon, Zehra Khan, and Nasir Mansoor in their contributions to this book, the surviving workers and family members of the deceased founded the Ali Enterprises Factory Fire Affectees Association (AEFFAA) with the help of NTUF and the Home Based Women Workers Federation (HBWWF).

As a first step in the cooperation, ECCHR assisted initial public interest litigation (PIL) proceedings led by advocate Faisal Siddiqi before the High Court of Sindh by submitting an amicus brief in 2014. The amicus brief outlined Pakistani authorities'

\footnotetext{
${ }^{54}$ ECCHR initiated a civil action brought by Hamburg's consumer protection agency asking Lidl to stop advertising its code of conduct, arguing that it was misleading consumers to believe that products available at Lidl Markets were produced in conditions respecting workers' rights, as proclaimed by the company's code of conduct. ECCHR, Complaint re Fair Working Conditions in Bangladesh. Lidl forced to back down, www.ecchr.eu/en/case/complaint-re-fair-workingconditions-in-bangladesh-lidl-forced-to-back-down/ (last accessed 12 September 2020).

${ }^{55}$ ECCHR filed OECD complaints against seven companies in France, the UK, Germany and Switzerland for their alleged role in trading cotton from Uzbekistan, which was known to be produced through state-organised, forced child labour at that time. ECCHR, The Cases against European Cotton Traders, www.ecchr.eu/en/case/the-cases-against-european-cotton-traders/ (last accessed 12 September 2020).
} 
obligation not only to investigate the responsibility of Pakistani actors, but also the role of the international retail and auditing companies. The next step in building the cooperation involved holding a series of workshops and assemblies with the AEFFAA, in which we discussed the possibilities and risks of a transnational legal claim against KiK and RINA. For the AEFFAA, as well as NTUF, medico and ECCHR, it was clear that the possibility of filing a civil compensation lawsuit was not primarily about gaining the much-needed compensation. Given the cost restraints, only a handful of victims could realistically bring a claim and, as such, it would hardly lead to compensation for all. The option of going to court in Germany against KiK offered the possibility to claim the rights of workers in global value chains rather than asking companies for a humanitarian gesture. It was seen as a chance to make a political claim for justice.

The risks of this approach were also obvious: lengthy procedures and slim chances of actually winning could exhaust the claimants and eventually leave the whole group disillusioned. The claimants would also expose themselves to the public, with all the pressures that this might entail. The decision-making process around whether to pursue the litigation against KiK or not included several meetings and workshops in Karachi and online. In the end, the AEFFAA nominated a group of 10 people who they felt could represent the whole group and their wider claim for justice, and who could also stand the pressure of the legal proceedings. ${ }^{56}$ Out of that group, ECCHR selected four people, as it was not possible to cover the litigation costs for all 10. As pre-trial negotiations with KiK stalled in the winter of 2014/2015, the AEFFAA together with ECCHR, NTUF and medico eventually decided to engage in the civil litigation against KiK. In March 2015, the surviving worker Muhammad Hanif, along with Muhammad Jabir, Abdul Aziz, and Saeeda Khatoon, all parents of deceased workers, brought civil action against KiK before the Regional Court of Dortmund, demanding 30,000 euros each in damages for pain and suffering.

While ECCHR, NTUF, medico and AEFFAA engaged in the civil litigation against $\mathrm{KiK}$ in Germany, filed a criminal complaint against RINA officials in Italy, and, later on, also lodged an OECD complaint in Italy, other organisations like PILER, ${ }^{57}$ the Clean Clothes Campaign, and the IndustriALL Global Union focused their efforts on negotiating a long-term compensation fund in accordance with the standards of the International Labour Organization, along the same lines as the Rana Plaza Compensation Agreement. Controversial discussions occurred between those who saw the ILO negotiations as the best route to pursue and those who preferred to opt for the lawsuit, as some feared the lawsuit would harm the negotiation strategy at the ILO and vice versa. ECCHR made a deliberate decision to

\footnotetext{
${ }^{56}$ Due to procedural restrictions in Germany, ECCHR did not see it as feasible to represent all 250 families in the civil litigation.

${ }^{57}$ PILER had accomplished an important first step in negotiating with KiK by achieving US $\$ 1$ million in immediate relief for workers at the end 2012. For more details, see the chapter by Faisal Siddiqi in this volume.
} 
put significant energy into the process of reaching a common understanding among all the different actors. A division among the groups collectively fighting for workers' rights would have been a major defeat of the groups' common ideals and would have weakened the broader struggle of workers to the benefit of companies. After many travels between Europe and Pakistan, and after many meetings and long discussions, all of the parties finally reached an agreement on how to work together in a way that would allow both strategies to mutually reinforce each other.

The "legal route," we decided, would aim to provide an accelerating effect on the ILO negotiations by serving as an implicit incentive for the company to engage in them. The lawsuit deliberately asked only for compensation to cover pain and suffering, while the ILO negotiations demanded compensation to cover the loss of income and medical costs. ${ }^{58}$ In this way, the lawsuit in Germany did not provide KiK with an argument for opting out of the ILO compensation talks. Meanwhile, those negotiating with the ILO actively endorsed the legal case as an important additional step. ${ }^{59}$ Over time, it seems that the pending lawsuit did indeed enhance KiK's willingness to agree to the terms of compensation suggested by the ILO: one week after the Dortmund court granted legal aid and legal standing to the Pakistani claimants and allowed the case into the discovery phase (Beweisaufnahme), ${ }^{60} \mathrm{KiK}$ agreed to pay an additional US\$5.15 million into the ILO Ali Enterprises compensation fund, breaking the almost 2-year deadlock in which the ILO negotiations had been stalled.

\subsection{The Litigation Against KiK: Procedure and Key Legal Arguments}

According to both Paragraph 17 ZPO (Zivilprozessordnung, the German Code on Civil Procedure) and Article 4 of the Brussels I Regulation, the Regional Court of Dortmund (Landgericht Dortmund) had jurisdiction over the case. In accordance with Article 4(1) of the Rome II Regulation, the applicable law in this transborder litigation was Pakistani civil law, which is strongly influenced by Indian and English jurisprudence. ${ }^{61}$ Following the established English case law, the claimants argued that KiK breached its duty of care towards the employees of the Ali Enterprises

\footnotetext{
${ }^{58}$ For more details on the compensation funds see the chapter by Ben Vanpeperstraete in this volume.

${ }^{59}$ See www.media.business-humanrights.org/media/documents/files/documents/PR_Pakistan_ KiK_lawsuit_2019_09_10_eng.pdf; Joint Press Release, 29 November 2018: Ben Vanpeperstraete from Clean Clothes Campaign makes clear: "The proceedings against KiK in Germany have contributed significantly to the compensation settlement." www.ecchr.eu/en/press-release/ hearing-in-kik-case-in-front-of-regional-court-in-germany/ (last accessed 12 September 2020).

${ }^{60}$ This should not be mistaken with the discovery phase in UK or US law. See: Saage-Maaß (2021).

${ }^{61}$ Khan v. Haleem, (2012) CLD (SC) 6 (2011), 8 (Khilji Arif Hssain, J., concurring) (Pak.); Khanzada v. Sherin, 1996 CLC 1440 (Peshwar) (Pak.), citing Indian law authoritatively in a case alleging medical malpractice.
} 
factory. ${ }^{62}$ The requirements for a duty of care are largely based on the decisions in Caparo v. Dickman and Chandler v. Cape, ${ }^{63}$ according to which, a duty of care is established under the following cumulative conditions: the harm that occurred was foreseeable, there was sufficient proximity between the parties, and the imposition of a duty can be seen as fair, just, and reasonable. ${ }^{64}$ The Regional Court of Dortmund was asked to assess the relevant duty of care and thereby had to assess the nature of the relationship between KiK and Ali Enterprises, the applicable industry standards of CSR, the relevant standards for safety audits, and KiK's duty in relation to such audits. ${ }^{65}$

The claimants argued that there was a clear economic dependence between $\mathrm{KiK}$ and Ali Enterprises, as KiK had purchased almost three quarters of Ali Enterprises' production output over the 5-year period preceding the fire. The claimants also argued that such an economic dependence created KiK's ability to influence and control the health and fire safety conditions under which Ali Enterprises ought to have conducted its business in Pakistan. The claimants further constructed KiK's obligation through a review of its 2009 code of conduct ${ }^{66}$ and a statement by KiK's managing director weeks after the factory fire that "the monitoring of adherence to safety and fire prevention is obligatory for us as a buyer." ${ }^{27}$ As KiK's code of conduct was incorporated into the terms and conditions of every purchasing order, the claimants argued that the company's public pledges on safe and ethical working

\footnotetext{
${ }^{62}$ Terwindt et al. (2018), p. 276.

${ }^{63}$ Caparo Industries plc v. Dickman [1992] 2 AC 605; Chandler v. Cape Plc [2012] EWCA Civ 525 (25 April 2012).

${ }^{64}$ Paragraph 80 of the Chandler appeal's decision provides key indicators of when a duty of care is owed by a multinational corporation parent, namely when: (1) the businesses of the parent and subsidiary are, in a relevant respect, the same; (2) the parent has or ought to have superior knowledge on some relevant aspect of health and safety in the particular industry; (3) the subsidiary's system of work is unsafe, which the parent knew or ought to have known; and (4) the parent knew or ought to have foreseen that the subsidiary or its employees would rely on its using its superior knowledge for the employee's protection. The Court also clarifies that for the purpose of (4), it is not necessary to show that the parent is in the practice of intervening in the health and safety policies of the subsidiary. Instead, the court should look at the relationship between the companies more widely. It may be enough to show that the parent has a practice of intervening in the trading operations of the subsidiary, for example, in production and funding issues.

${ }^{65}$ Terwindt et al. (2018), p. 268.

${ }^{66} \mathrm{Here}, \mathrm{KiK}$ stated in the section titled "Standard for Employment" in regards to "Health and Safety at Work" in its supply chain that: "The workplace and the practice of the work must not harm the employees' or workers' health and safety. A safe and clean working environment shall be provided. Occupational health and safety practices shall be promoted, which prevent accidents and injury in the course of work or as a result of the operation of employer facilities. These safety practices and procedures must be communicated to the employees as well as the workers; they have to be trained in effective usage [...]." KiK Textilien und Non-Food GmbH, Code of Conduct, revised version, 1 August 2009, p. 3.

${ }^{67}$ KiK Textilien und Non-Food GmbH, Statement on the Panorama Program of 6 December 2012, translation by the author.
} 
conditions caused legal obligations: self-regulation must lead to legal obligation. ${ }^{68}$ Finally, the claimants also argued for vicarious liability, which provides for the strict liability of the employer, but also of the principal in a relationship "akin to employment." The concept of vicarious liability under common law is more flexible than it is under German law, as it is not necessarily based on a formal contractual relationship but instead rests on the overall circumstances of a business relationship between two parties examined through a five-factor lens. ${ }^{69}$

KiK defended itself by restating its corporate social responsibility narrative, which presents the company as truly committed to improving working conditions in its suppliers' factories and as taking concrete efforts to achieve this end. At the same time, KiK denied any form of liability, arguing that, as a fully independent legal entity, Ali Enterprises was the only duty bearer for its employees' safety. KiK admitted to having sent its own personnel to visit the production site, to having commissioned several social audits of the Ali Enterprises factory, and to having obliged its suppliers to sign the company's code of conduct. Despite all of this, KiK claimed to have no ability to influence, let alone control, the fire safety standards of the Ali Enterprises factory. Referring to the social audit reports that KiK itself had commissioned, which displayed little to no deficiencies in fire safety, the company additionally claimed that they could not have possibly known about the real state of fire safety and, therefore, could not be legally liable. KiK insisted that corporate social responsibility measures do not imply any legal responsibility. The social audit reports served as a proof of the fact that $\mathrm{KiK}$ was under the assumption that general working conditions, and fire safety in particular, were in accordance with their code of conduct. KiK's legal briefs follow the classic industry narrative: "We are concerned about workers' rights and do all we can, but we do all of this purely voluntarily, and take no responsibility."

While the claimants in the KiK case had negotiated a waiver on the statute of limitations in pre-trial negotiations, KiK claimed in the litigation that the case was time-barred under Pakistani law. In a decision based on the expert opinion of a British law professor it had commissioned, the Dortmund court eventually held that the negotiated waiver was invalid because the case was governed by Pakistani law, which does not provide for the possibility of such a waiver. The claimants' attempt to argue that the waiver was governed by German law, because both the representatives of the claimants and the defendant were German lawyers using German legal language, and therefore implicitly agreeing on the application of German law, did not succeed. As a result, the court only superficially dealt with the question of which duties of care a buyer may owe towards the employees of a subsidiary. ${ }^{70}$

\footnotetext{
${ }^{68}$ Beckers (2017), pp. $15 \mathrm{ff}$.

${ }^{69}$ E v. English Province of Our Lady of Charity [2012] EWCA (Civ) 938, [2013] 2 W.L.R. 958, $19,70 \mathrm{ff}$.

${ }^{70}$ LG Dortmund, 7 O 95/15, Beschluss 10 January 2019.
} 


\subsection{The Legal Interventions Against the Social Auditing Firm RINA}

Parallel to the legal action against KiK, Italian lawyers filed criminal charges against the managing director of RINA on behalf of the AEFFAA, NTUF and ECCHR in 2014. The allegation was that top managers of RINA, who had allowed for the issuance of the SA-8000 certificate weeks before the fire in 2012, were liable under Italian criminal law for the crime of giving false certification and falsification of documents. ${ }^{71}$ The investigating judge in Turin opened the criminal proceedings and ordered expert opinions on the causes of the fire, but then handed the case over to the public prosecutor in Genoa for jurisdictional reasons. There, the investigative judge closed the proceeding in December 2018 after an appeal, ${ }^{72}$ holding that it would be hard to argue in court that the issuing of the SA-8000 certificate had been causal to the fire. In her view, RINA Services could not have prevented the factory's continued operation in the absence of adequate safety conditions for workers, and therefore RINA could not have prevented the fire. With regard to the RINA top manager under investigation, the judge did not see sufficient evidence to indicate that he had been aware of the alleged falsification of the audit report, which was the basis for the issuance of the SA-8000 certificate. Furthermore, in her assessment, RINA managers did not commit the crime of giving a "false statement," as the certification was not legally mandatory, but only issued upon the voluntary request of individual companies, mostly driven by market demand.

As RINA's activities are not only subject to Italian criminal jurisdiction, but also to the OECD Guidelines for Multinational Enterprises because Italy is an OECD member state, the above-mentioned organisations, together with a broader international coalition, filed a complaint against RINA with the OECD National Contact Point in Italy in September 2018. While the National Contact Point treated the complaint in a very swift but thorough manner, RINA management also proved to be very reluctant to accept any responsibility under the soft law standard of the OECD guidelines. The parties, therefore, did not reach an agreement in the negotiations.

\footnotetext{
${ }^{71}$ Art. 477 Codice Penale (Italian Criminal Code): falsità materiale; Art. 479, 480, 481, 482 Codice Penale: falsità ideologica.

${ }^{72}$ Tribunale de Genova, Ufficio del Guidice per le Indagini Preliminari, Decreto di Fissazione dell' Undienza a seguito di opposozione-art. 409 c2 c3 c.p.p., $N$ 3240/16/N 10400/16, 11 December 2018.
} 


\section{Objectives and Achievements of the Transnational Legal Interventions in the Wake of the Ali Enterprises Fire}

So, what were the effects of the transnational litigation in the wake of the 2012 Ali Enterprises fire? What did the surviving workers of the Ali Enterprises fire and the family members of the deceased achieve? Did the transnational legal interventions change any legal, social, or political realities to the advantage of workers in globalised value chains?

The self-defined objectives of those engaged with the litigation offer perhaps the best benchmark against which to measure the litigation's effects in this regard. As Saeeda Khatoon, the mother of one of the fire's victims and a representative of the AEFFAA, describes the goals of the litigation against KiK: "Our aim was not compensation, it was justice. We needed to fight for our children's safety against the international brand $[\mathrm{KiK}]$, to deter them from enabling this again. So that something like this does not happen to other children."73 Meanwhile, NTUF, medico, and ECCHR claim that "in conceptualising the legal case against $\mathrm{KiK}$ in Germany, [they] agreed to promote the factory fire affectees' demand for compensation as a right in itself. From the beginning, we sought to frame the court case against KiK in Germany as a political statement, not just a legal dispute." ${ }^{, 74}$ NTUF also sought to stress the point that working conditions in factories producing for the international market are just as exploitive as elsewhere, meaning that the struggle to organise and demand workers' rights must be fought in all workplaces throughout Pakistan. In sum, the KiK case was not just designed as legal case in the technical sense, but as a case with the wider political aim of challenging corporate irresponsibility in today's globalised capitalist economy by making the legal argument that lead firms like KiK do in fact bear legal responsibility for conditions that prevail in their supply chains.

Despite the abundance of literature describing the relationship between law, litigation, and social change, it is still difficult to find adequate parameters for measuring the effects or impact of human rights litigation. ${ }^{75}$ Many authors describe at least three effects of strategic litigation. First, the most obvious effect is precedence-setting: when court decisions change the reading of the law and its application in the way intended by the litigators. Unlike in the continental European setting where courts have the ability to change the interpretation and application of laws, in Anglo-American legal systems court can even create law. ${ }^{76}$ Second, court cases can help movement-building and strengthen civil society

\footnotetext{
${ }^{73}$ See the interview with Saeeda Khatoon by Palvasha Shahab in this volume.

${ }^{74}$ See chapter by Mansoor et al. in this Volume.

${ }^{75}$ Duffy (2018), Marshall and Hale (2014), McCann (2008) and Lobel (2003).

${ }^{76} \mathrm{Next}$ to this practice of using emblematic cases to set precedents before the higher courts, Ulrike Müller has pointed out that clients can also be strategically represented in more ordinary cases, not aimed at precedence-setting, but rather serving as acts of resistance, like cases of police violence against protestors or asylum cases. Müller (2019), pp. 50-51.
} 
organisations that pursue wider goals of social change, beyond the individual litigation. ${ }^{77}$ Within the context of international crimes, self-empowerment is often described as a positive effect of strategic litigation, as the harmed party can regain control over the narrative of the crimes suffered and actively demand justice. ${ }^{78}$ Finally, strategic litigation cannot only help shape legal discourses, but it can also spur wider public debates. Independent from whether a case is won or lost, filing a lawsuit can create a sense of injustice among the public, a sense that something needs to be corrected, if not through the courts then by parliamentarian action and legal reform. $^{79}$

\subsection{Self-empowerment}

In September 2012, the surviving workers and the families of the deceased from the Ali Enterprises fire were not organised in any way. The one thing that connected them was the tragic experience of a workplace disaster that, for many, resulted in the loss of a family member. With the help of NTUF, however, they started to organise and support each other, both in the daily struggles of families having lost their breadwinners, and in more political work demanding justice and changes in Pakistani labour law. ${ }^{80}$ While in the Rana Plaza incident, the affected workers did not organise in a way that would allow an organisation to speak for the wider group, the AEFFAA became, over the course of the last 8 years, an organisation recognised by the ILO, the Pakistani government, and global unions as the legitimate representative of the people affected by the Ali Enterprises fire. Although media and humanitarian relief efforts have often treated workers as passive victims and recipients of charitable assistance only interested in financial compensation, ${ }^{81}$ the fact that the workers in the Ali Enterprises incident drove their own legal proceedings as an organisation, both on the domestic and the transnational level, helped others to see them differently, as people acting on their own behalf, refusing to be mere objects of others' policy considerations. Indeed, after the filing of the lawsuit in Germany, the AEFFAA was part of the compensation negotiations at the ILO and was able to exert substantial influence over how the negotiations developed.

Through the civil litigation against KiK in Germany, the four claimants, all workers from Pakistan, were able to force the transnational company KiK to listen

\footnotetext{
${ }^{77}$ McCann (2008).

${ }^{78}$ Duffy (2018), pp. 48-50.

${ }^{79}$ McCann (2008) and Lobel (2003). On the societal level, the goal behind instigating criminal trials against an alleged perpetrator of international crimes is often to create a narrative that acknowledges the grave crimes that were committed, which then enables a society to transition to a fair and just, peaceful society.

${ }^{80}$ See the interview with Saeeda Khatoon by Palsvahsa Shahab in this volume.

${ }^{81}$ Sumon et al. (2017).
} 
and respond to their claims-simply through the exchange of legal briefs and arguments. The four Pakistani claimants became unavoidable for KiK; its CEO and other managers had to hire expensive law firms to deal with the arguments they brought forth. KiK clearly needed to be forced into this engagement and still did everything possible to avoid personal interaction. On the day of the oral hearing in Dortmund, no KiK manager showed up in the courtroom, only their legal representatives. To this day, KiK still denies Khatoon and the rest of the AEFFAA the respect of meeting with them in person.

Equally disappointing is the situation in Pakistan, where the criminal procedure around the Ali Enterprises fire obtained a first instance judgement in autumn of 2020, in which the factory owners were acquitted from responsibility and all of the criminal charges were put on clandestine criminals for arson. ${ }^{82}$ This has shifted the public narrative in Pakistan away from workers' rights to a focus on a "terrorist attack" in which the factory owners are portrayed as the victims. On the one hand, this is a clear insult to all that the AEFFAA and others involved in the struggle for justice stand for. On the other hand, however, this verdict was based on weak evidence and included the handing down of a death sentence by one of Pakistan's notorious and much-criticised Anti-Terrorism Courts, ${ }^{83}$ which could potentially delegitimise the whole endeavour of those trying to shift the narrative away from workers' rights.

While it is too early to determine how the narrative about the Ali Enterprises factory fire will eventually be shaped in Pakistan, it is important to note that those deprived of dignity through industrial exploitation were able to act in selfdetermination. They became actors in Pakistan and internationally who could no longer be ignored by those driving economic decisions in global value chains as well as in international compensation processes. For the main organisations involved in the case and the cooperation that evolved around it, the experience also had empowering effects. NTUF has reported that engaging in transnational cooperation, and in transnational litigation in particular, has helped to raise its profile in the Pakistani context, which helps it have more influence in the workers' rights movement in Pakistan. For medico and ECCHR in Germany, the chance to work so closely with the Ali Enterprises fire survivors and family members of the deceased, as well as those directly supporting them in Pakistan, not only helped guide the work on the legal case, but also gave legitimacy to the political arguments they raised.

\footnotetext{
${ }^{82}$ Judgement 22 September 2020, In the Anti-Terrorism Court No: VII, Central, Prison, at Karachi. (Special case No: 11 (vii)/2017) EX. No: 492, Document Code: 68D2CAF5EDFA415A0FFB9436A587BF78.

${ }^{83}$ Yusuf (2010).
} 


\subsection{Intervention in the Legal Discourse}

The most obvious result of the strategic use of legal proceedings is to set legal precedence. To some extent, the litigation before the civil court in Dortmund did set precedence procedurally, as for the first time in Germany a court granted legal standing and legal aid to workers suing a retailer for damages that occurred in a suppliers' factory outside of Europe. ${ }^{84}$ The fact that workers from Pakistan came to German courts asking for compensation from a well-known German retailer was perceived both by media as well as legal scholars as a novelty, and therefore, in a less technical sense, as precedence-setting. The litigation against KiK was also rather novel on an international level given that, up until this point, litigation against transnational corporations had primarily targeted parent companies for rights violations in subsidiaries. To legally hold a lead firm responsible for labour rights violations in its supply chain still remains rare. ${ }^{85}$

Still, several points prevent an overly positive assessment of the case's legal success. First, the merits were never decided on, as the court dismissed the case as time-barred and, hence, never dealt with the question of KiK's duties of care. Therefore, precedence could not be established on the question of international buyers' liability for rights violations in their supply chains. In addition to this, there were also downsides with regard to the claimants' access to justice. Saeeda Khatoon was the only one of the four claimants who was able to attend the first and only oral hearing before the Dortmund court in person. The other claimants were either denied visa, as EU policies aim to keep young working-class men from Pakistan out of Europe, or they were hindered from traveling by old age. In the courtroom, the presiding judge denied Khatoon the chance to speak, as he felt she would not have anything "relevant" to contribute to the legal question of statutes of limitation. As this was within the procedural rules, the legal case was debated among the legal experts before the Dortmund court. German civil procedural law allowed the case to be discussed without the voice of those affected and, in the end, offered very little material success to the four claimants from Pakistan.

One aspect that turns the analysis of the lawsuit once again to a more positive note, is that it had positive effects on KiK's willingness to engage in the ILO compensation negotiations and, eventually, to pay the workers a substantial amount

\footnotetext{
${ }^{84} \mathrm{~A}$ few months after the KiK case, another important case was filed: a Peruvian farmer brought a civil action against the energy corporation RWE claiming that it needed to pay for the damage on his property stemming from climate change. The case was declared admissible and went into the trail stage in November 2017, where it is still pending. OLG Hamm, I-5 U 15/17, Hinweis- und Beweisbeschluss 30 November 2017.

${ }^{85}$ Lobslaw, which had a supplier factory in the Rana Plaza Building, and Bureau Veritas, which audited the factory, were sued in Canada by Bangladeshi survivors of the Rana Plaza building collapse only a few weeks after the case against KiK was filed in 2015. The Ontario appeals court dismissed the case in December 2018. Das v. George Weston Limited, 2018 ONCA 1053 (CanLII) www.canlii.org/en/on/onca/doc/2018/2018onca1053/2018onca1053.html (last accessed
} 12 September 2020). 
of money. The negotiation route gave the company an opportunity to showcase its commitment to corporate social responsibility without acknowledging liability. So, even if the court cases did not deliver compensation, the claimants and all other affected persons eventually received further compensation from KiK, though without recognition of legal responsibility, of course.

Further, the lawsuit in Germany had a visible impact on German legal debate. Even though the case against $\mathrm{KiK}$ was lost, it brought up several paradigmatic problems of liability in global value chains and made clear that more cases of this kind raising similar questions of liability are likely to come. ${ }^{86}$ The KiK litigation also contributed to ongoing scholarly debates in which the strict application of the principle of limited liability to constellations of transnational human rights violations caused by subsidiaries is increasingly called into question, with a plea made to extend liability standards within the corporate group. ${ }^{87}$ Authors increasingly point out that soft law standards such as the OECD guidelines or the UNGPs and their implementation in corporate practice can concretise companies' tortious duties of care also with regard to liability for damages occurring in supplier companies. ${ }^{88}$ In particular, authors dispute which actual and normative factors constitute liability and the standards according to which the extent of liability should be determined. ${ }^{89}$ Several authors are also working to further develop the reasoning on parent companies and lead firms' potential duties of care with regard to their foreign subsidiaries and suppliers. ${ }^{90}$

\subsection{Intervention in the Public Discourse}

From early on, the AEFFAA engaged with NTUF in political work, as they sought to "prevent such disasters" from happening again. ${ }^{91}$ For many members of the AEFFAA, the transnational litigation against KiK offered a possibility to bring forth their demands for structural changes regarding workplace safety and workers' rights in local and national politics. As Khatoon reflected:

\footnotetext{
${ }^{86}$ Osieka (2014), Wagner (2016), Weller et al. (2016), Weller and Thomale (2017), Thiede and Bell (2017), Thomale and Hübner (2017), König (2017), Mansel (2018), Nordhues (2019), Wendelstein (2019), Haider (2019), Von Falkenhausen (2020) and Habersack and Ehrl (2019), two of four articles in the special issue "Human Rights Violations in Global Supply Chains" of the Journal of European Tort Law start their discussion with the example of the litigation against KiK: Spitzer (2019), pp. 95-107; Geistfeld (2019), pp. 130-165.

${ }^{87}$ Wagner (2016), p. 717; Wagner (2017), para. 99; König (2017), p. 611; Schall (2018), p. 479, Habersack and Ehrl (2019).

${ }^{88}$ Segger (2018), pp. 47 ff.; Heinen (2018), p. 87; Thomale and Hübner (2017), p. 394.

${ }^{89}$ Leader and Vastardis (2018), Improving Paths to Business Accountability for Human Rights Abuses: A Legal Guide. University of Essex Business and Human Rights Project.

${ }^{90}$ Heinen (2018), pp. $96 \mathrm{f}$.

${ }^{91}$ See above footnote 74 .
} 
Due to these transnational collaborations, we were able to project the incident and talk about it on various platforms. We were able to draw attention to our cause. The money does not mean anything. It is worth nothing against the joy we would have had if our children were still around. What is money? Money gets spent. But these collaborations allowed us to not be forgotten. If we can work to save lives, prevent deaths - that, for us is the biggest motivation. $^{92}$

NTUF, medico and ECCHR similarly saw the European public discourse as an important field of intervention and, accordingly, looked for ways to make the story of the Ali Enterprises fire and the workers' claims for justice prominent beyond the actual legal procedure. For example, they organised two speakers' tours for the plaintiffs in Germany, Geneva, and Italy in 2016 and 2018. In 2016, Saeeda Khatoon and Abdul Aziz spoke with German members of parliament in Berlin and with a secretary of state from the ministry of development. They also spoke in townhall meetings and to high school classes around Dortmund and Düsseldorf. The goal of this tour was to give journalists, politicians, and an interested public the opportunity to meet the claimants in person and to hear their claims in a direct encounter.

In the process of reaching out to a wider public to gain support for the cause of the workers and families of the AEFFAA, artists played an important role, as did journalists. $^{93}$ For example, Forensic Architecture, ${ }^{94}$ a multidisciplinary research and media group based at Goldsmiths University of London that uses architectural techniques and technologies to investigate cases of human rights violations, created a visual reconstruction of the Ali Enterprises fire incident that helped to underline the credibility of the legal case and the legitimacy of the AEFFAA's demands. ${ }^{95}$ The reconstruction was based on all available official records from Pakistan and used new evidentiary techniques and advanced architectural and media research. The final product was a 20-minute video that reconstructed the events at the Ali Enterprises factory on 11 September 2012, and simulated how many workers could have been evacuated if only basic fire safety precautions had been respected. The narrative of the factory fire being a terrorist attack, which caught on among the public in Pakistan, ${ }^{96}$ never really gained traction in Germany or Europe.

In anticipation that the Dortmund court might not decide in favour of the claimants and that, ultimately, the case would not be won in court, NTUF, medico and ECCHR organised a "Week of Justice" around the oral hearing in Dortmund in

\footnotetext{
${ }^{92}$ See the interview with Saeeda Khatoon by Palsvasha Shahab in this volume.

${ }^{93}$ See the interview with Adeela Suleman by Palvasha Shahab in this volume for the perspective of a Pakistani artist.

${ }^{94}$ Forensic Architecture, www.forensic-architecture.org/ (last accessed 16 September 2020).

${ }^{95}$ For the film, see footnote 46; one of the major German TV channels (ZDF) broadcasted part of the reconstruction on 1 February 2020 in its 5 pm news show. Several newspapers also reported on it, for example: Dohmen C, Simulation eines Infernos. Süddeutsche Zeitung, 31 January 2018, www. sueddeutsche.de/wirtschaft/unglueck-von-karatschi-2012-simulation-eines-infernos-1.3848299? reduced $=$ true (last accessed 16 September 2020).

${ }^{96}$ See chapter by Faisal Siddiqi in this volume.
} 
November 2018. ${ }^{97}$ The Week of Justice sought to make the claim for justice visible in the public domain beyond the courtroom, using the media attention the court procedure would raise. Khatoon spoke in this week at one of the opening plenary sessions of the UN Forum on Business and Human Rights in Geneva, ${ }^{98}$ at press conferences in Dortmund and Rome, at an event at the Theatre of Dortmund on the Ali Enterprises case, and in a symposium at the University of Bochum on questions of "Corporate Liability in Global Supply Chains."

Through Khatoon's testimony and those of other workers like Mohammed Hanif and Abdul Aziz, the deceased and surviving workers of the Ali Enterprises factory, who usually remain anonymous, became real people with whom the German public could relate. ${ }^{99}$ The Pakistani workers embodied the essence of human dignity in confronting the European public with the inequalities and injustice of the global economy. This can help explain the growing interest of a wider public in Germany in the case against $\mathrm{KiK}$, but also in the issue of exploitative working conditions in global supply chains more broadly since 2012 . The fact that the claimants lost the case was perceived as "unjust" by a wide range of commentators in print media, as well as on television. From left-leaning newspapers to the prestigious conservatives, all took up the narrative that the case against $\mathrm{KiK}$ highlighted the problem of exploitation in global value chains and that retailers like KiK should bear responsibility. ${ }^{100}$ When the case was lost, most journalists concluded that the existing law obviously falls short, if claimants could not get justice in such a case.

There is also reason to believe that the legal and public debates around the KiK case influenced a law reform process in Germany. The first formal proposal for a supply chain liability law in Germany was published just a few weeks after the KiK case was dismissed. In continuing debates around the so-called supply chain law (Lieferkettengesetz), the KiK case is often cited as a reference point, as the case's

\footnotetext{
${ }^{97}$ ECCHR, One Week of Justice, www.ecchr.eu/en/event/one-week-of-justice/ (last accessed 12 September 2020).

${ }^{98}$ Panel on Voices from the Ground-Forum on Business and Human Rights 2018, www.webtv.un. org/watch/panel-on-voices-from-the-ground-forum-on-business-and-human-rights-2018/ 5971600547001/ (last accessed 12 September 2020).

${ }^{99}$ Christopher Patz, Discount Workers www.youtu.be/_sXuvORQkqc (last accessed 12 September 2020).

${ }^{100}$ Klage gegen Kik abgewiesen. Frankfurter Allgemeine Zeitung, 11 January 2019, p. 20, "Deutsche Unternehmen aller Branche hätten die Klage gegen Kik genau verfolgt, stellte Miriam Saage-Maaß von der Bürgerrechtsorganisation ECCHR fest: Allen ist klar: Das aktuelle Recht wird der globalisierten Wirtschaft nicht gerecht."; Kein Urteil gegen KiK, Tageszeitung, 10 January 2019, "Die Kläger wollen erreichen, dass die Arbeitsbedingungen in der ausgelagerten Textilproduktion in armen Ländern grundsätzlich besser werden." www.taz.de/Prozess-wegenFabrikbrand/!5561365/ (last accessed 12 September 2020); Böker C, KiK muss pakistanischen Arbeitern kein Schmerzensgeld zahlen. Das ändert nichts daran, dass sich die Textilindustrie ändern muss. Denn der Kunde ist schwach. ZEIT ONLINE, 10 January 2019, www.zeit.de/zeit-magazin/ mode-design/2019-01/fast-fashion-kik-fabrikbrand-pakistan-textilbuendnis (last accessed
} 12 September 2020). 
dismissal proves the point that law reform is needed. ${ }^{101}$ For example, the civil society campaign for a supply chain law in Germany, but also its counterpart at the EU level, refer to the case as a "real-life" example in which a duty of care should be clearly established by law. ${ }^{102}$ Nasir Mansoor of NTUF and Saeeda Khatoon of the AEFFAA contributed a video statement in support of law reform in Germany for the launch of the civil society campaign and also spoke before the European Parliament. ${ }^{103}$ Studies commissioned by both the European Commission and European Parliament assessing the need for law reform have also made reference to the KiK litigation. $^{104}$

To sum up, in a narrow legal sense, the effects of the cases against KiK and RINA were restricted to procedure: the cases confirmed that workers from outside the EU have legal standing and can apply for legal aid to bring civil claims for compensation or criminal complaints against retailers and auditing companies in European jurisdictions. The merits were not decided upon, leaving the issue of corporations' duty of care towards their supply chains an open question that will need to be addressed through future cases. The litigation created a space in which those affected could raise their voices to a wider public, report on their experiences, and formulate claims in the EU and on the international level. It was not only the court proceedings, through the filing of legal briefs, that allowed the claimants to raise their demands, but equally important was that the "news" of Pakistani workers suing a German

\footnotetext{
${ }^{101}$ Misereor, Dismissal of complaint in KiK case shows serious gaps in the German legal system, 10 January 2019, www.misereor.de/presse/pressemeldungen-misereor/klageabweisung-im-kikfall-zeigt-gravierende-luecken-im-deutschen-rechtssystem/ (last accessed 12 September 2020).

102،Angehörige von Todesopfern, wie im KiK-Fall, müssen oft nicht nur den Verlust hinnehmen, sondern stehen auch noch mittellos da. Die Initiative Lieferkettengesetz will, dass Betroffene auch vor deutschen Gerichten Entschädigung einklagen können, wenn ein Unternehmen seinen menschenrechtlichen Pflichten nicht nachgekommen ist.", Initiative Lieferkettengesetz, Warum wir ein Lieferkettengesetz brauchen, 4 September 2019, www.lieferkettengesetz.de/wp-content/ uploads/2019/09/Initiative_Lieferkettengesetz_Basisflyer_148x148_SCREEN.pdf (last accessed 12 September 2020); Anti Slavery International and European Coalition for Corporate Justice, What if? Case studies of human rights abuses and environmental harm linked to EU companies, and how EU due diligence laws could help protect people and the planet, 11 September 2020, www. corporatejustice.org/eccj-publications/16830-what-if-case-studies-of-human-rights-abuses-andenvironmental-harm-linked-to-eu-companies-and-how-eu-due-diligence-laws-could-help-protectpeople-and-the-planet (last accessed 19 September 2020), pp. 11-13.

${ }^{103}$ ECCHR, Sieben Jahre nach dem Brand bei KiK-Zulieferer: Betroffene berichten, www.youtube. $\mathrm{com} /$ watch $\mathrm{v}=$ PbrqRZMod-A\#action=share (last accessed 19 September 2020).

${ }^{104}$ European Commission, Study on due diligence requirements through the supply chain. Final Report, p. 215, www.op.europa.eu/en/publication-detail/-/publication/8ba0a8fd-4c83-11ea-b8b701aa75ed71a1/language-en (last accessed 12 September 2020); European Parliament, Study: Access to legal remedies for victims of corporate human rights abuses in third countries, pp. 59-65, www.europarl.europa.eu/RegData/etudes/STUD/2019/603475/EXPO_STU(2019) 603475_EN.pdf (last accessed 12 September 2020).
} 
retailer attracted wide public attention, allowing for meaningful interventions into the public discourse. ${ }^{105}$

\section{The Emancipatory Potential of Legal Interventions: Towards a Holistic Approach}

Law must be understood as a product of societal struggles for hegemony and not only as the "immediate arm of the powerful." 106 While law represents the hegemonic interests of capital and the enduring imperial way of life in the Global North, it also has its own interior logic through which it withdraws from the immediate control of the powerful. On the one hand, law's abstractions and fictions are protective mechanisms against the most egregious assaults on human life and dignity. ${ }^{107}$ On the other, the relative autonomy of the law creates space in which to challenge the hegemonic reading and make-up of the law itself. Lawsuits and legal proceedings can therefore be used as one way to engage in counter-hegemonic and emancipatory struggles. ${ }^{108}$ Because Wendy Brown rightfully concludes that rights are something we "cannot not want," we must acknowledge the paradoxes of law by finding an emancipatory approach to legal practice, which must be much broader than a narrow focus on legal procedure and rights claims. ${ }^{109}$ We need a "power-oriented approach" to legal practice that inherently seeks to challenge repressive power structures. ${ }^{110}$ This approach interprets rights in an emancipatory way and, even more, focuses on creating a genuine awareness of the political, social, and economic struggles that underlie any given legal case.

Applying this reasoning to the case against KiK reveals that the plaintiffs both used and countered the inherent logic of the law. They used the inherent logic of the law in the sense that the fiction of procedural equality before the law is what enabled four Pakistanis to go before the Regional Court of Dortmund in Germany to represent the workers of South Asia and demand compensation for the losses they suffered at the hands of a transnational company much more powerful than they are. At the same time, the KiK claim also countered the logic of the law in the sense that the plaintiffs and their lawyers demanded rights that, according to the current tort law doctrines, they cannot claim. In their legal argument the plaintiffs and their lawyers

\footnotetext{
${ }^{105}$ Several members of the AEFFAA are by now also active in the HBWWF, in which they organise themselves and the home-based women workers in their communities. In cooperation with NTUF and HBWWF, they have also managed to achieve some substantial legislative changes in the province of Sindh.

${ }^{106}$ Buckel (2009), p. 19.

${ }^{107}$ Williams (1987).

${ }^{108}$ Buckel (2015), p. 313.

${ }^{109}$ Brown (2000), p. 240.

${ }^{110}$ Gabel and Harris (1982-1983), p. 375; Knuckey et al. (2020), pp. 125 ff.
} 
interpreted the existing Pakistani tort law in a way that acknowledges the rights of workers in global value chains. With this, the organisations and lawyers involved aimed to create a new understanding of legal obligations in economic relationships along globalised supply chains. If the reasoning brought forth by the claimants in the KiK case were to become the dominant reading of the law, companies at the top of supply chains, those that gain most of the profits, would have legal obligations"duties of care"-towards workers in their supply chains. The legally organised "irresponsibility" of lead firms would be reversed, as lead firms bearing a tort law duty of care towards the workers in their supply chains would need to substantially change their mode of production. If workers could regularly challenge the violation of their rights and hold the most powerful actors along the chain responsible, lead firms would have to find other ways of engaging with their supplier companies, their management, and their workers. They would likely need to change their buying and pricing practices altogether.

Using the language of rights in such a way allows utopian claims to be negotiated in legal forums that are usually subject to current legal systems and designed to preserve the status quo of those in power. ${ }^{111}$ The KiK case shows that it is possible to invoke the law as it is, and at the same time, present claims that go beyond the status quo, that anticipate a different law to come. ${ }^{12}$ This turns legal practice aimed at resistance into a practice aimed instead at emancipation, reaching for a different future. In the example of Pakistani workers suing KiK for damages, the utopian claim lies in the fact that our current economic system would not exist if textile workers and the international company were truly equal before the law. If textile companies could not externalise the social costs of production, the current economic system would not exist. The very act of Pakistani workers using the current legal system and its fiction of equality before the law challenges the status quo. It shows that the world economy and the legal system that would support their claim must be completely different than the one we have today. This is what others have called the revolutionary potential of human rights. ${ }^{113}$

This kind of lawyering understands legal strategy as only one of the many aspects that determine the overall strategy of the coalition of actors involved in a given emancipatory struggle. It is not centred on legal proceedings as such. Therefore, the lawyers' perspective on which jurisdiction, which course of action, and which legal arguments to use is balanced with other considerations on how to gain momentum in political debates and other forums relevant for the overall struggle. As the KiK case shows, it is particularly those actors who engage with the legal proceeding not as lawyers, but as artists, journalists, activists, and trade unionists that help the litigation to gain the momentum needed to have an impact beyond the courtroom.

\footnotetext{
${ }^{111}$ Bader et al. (2019).

${ }^{112}$ Horst (2019), p. 179; "Nur rechtliche Strategien, die entgegen allem Realismus unterstellen, dass das andere Recht schon da ist, können dazu beitragen, dass es einmal hervorgebracht wird." Menke (2018b), p. 28.

${ }^{113}$ Möller and Raimondi (2015).
} 
Therefore, the kind of lawyering described here pays attention to how different actors engage with each other. The actors in the KiK litigation aimed to create a transnational cooperation conscious of the power dynamics between lawyers and clients, and between organisations from the Global North and the Global South, that seeks to constructively engage these dynamics. ${ }^{114}$ Lawyers working and living in the Global North must engage with individuals and groups affected by corporate exploitation in solidarity, using their privileges in a way that is driven by the interests of the affected communities. ${ }^{115}$ This requires processes of reflection on different actors' political views and an honest analysis of privileges and power dynamics. It requires the building of a trustful partnership attentive and responsive to cultural, ideological, gender, and class differences.

\section{Conclusions}

The different legal proceedings against KiK and RINA must be seen in the broader context of the economic, social, and legal realities of globalised value chains. While international and national trade and commercial law generally enable lead firms in the Global North to maximise their profits, with these lead firms, in turn, bearing no legal responsibility for the exploitation of workers or the destruction of the environment, globalised value chains also open up possibilities for legally challenging the status quo. In the litigation against KiK, it was German civil procedure and Pakistani tort law that allowed four Pakistani workers to go to court in Germany to claim that lead firms actually do bear a duty of care for the workers in their globalised supply chains who they usually try to externalise.

Regardless of the proceedings' final outcome, the lawsuit against KiK had emancipatory effects because the efforts of the actors involved were not only focused on winning the legal case itself. All of the actors involved understood the legal case to be an opportunity for building a transnational alliance based on solidarity and a commitment to work together on an equal footing. They anticipated the potential shortcomings of the law and legal procedures and aligned the legal strategies with broader political goals of public outreach campaigning, advocacy efforts, and engagement in alternative political processes. This was only possible due to the cooperation of diverse actors from Pakistan and Germany, collectively comprising a diverse range of perspectives beyond legal expertise. ${ }^{116}$ Indeed, it was precisely the non-lawyers who played the most crucial roles, because they helped the legal debate

\footnotetext{
${ }^{114}$ See chapter by Mansoor et al. in this volume.

${ }^{115}$ Knuckey et al. (2020); Ancheita and Terwindt (2015); Hoffman and Vahlsin (2014); Gabel and Harris (1982-1983), p. 376.

${ }^{116} \mathrm{Kaleck} \mathrm{W}$, In the legal struggle for human rights, one must use all opportunities and develop a broad strategy. Open Global Rights, 26 February 2019, www.openglobalrights.org/seizingopportunities-and-broad-strategy-both-essential-in-human-rights-litigation/?lang=German (last accessed 12 September 2020).
} 
become socially and politically relevant: from the Pakistani workers, who as a group and individually, were prepared to expose themselves and take a public stance, to the courageous trade unions and civil society organisations that accompanied the selforganisation of those affected and had the willingness and skills to enter into the ILO negotiations, to the art and media professionals who made the case and the injustice perceptible to a broader public.

\section{References}

Ancheita A, Terwindt C (2015) Towards genuine transnational collaboration. Forschungsjournal Soziale Bewegungen 28:56-61

Anghie A (2004) Imperialism, sovereignty and the making of international law. Cambridge University Press, Cambridge

Anner M (2020) Squeezing workers' rights in global supply chains: purchasing practices in the Bangladesh garment export sector in comparative perspective. Rev Int Polit Econ 27 (2):320-347

Baars G (2019) The corporation, law and capitalism. A radical perspective on the role of law in the global political economy. Haymarket Books, Chicago

Baars $\mathrm{G}$ et al (2016) The role of law in global value chains: a research manifesto. London Rev Int Law 4(1):57-79

Bader M, Saage-Maaß M, Terwindt C (2019) Strategic litigation against the misconduct of multinational enterprises: an anatomy of Jabir and Others v KiK. Verfassung und Recht in Übersee 52(2):156-171

Barrientos S, Gereffi G, Pickles J (2016) New dynamics of upgrading in global value chains: shifting terrains for suppliers and workers in the global south. Environ Plann 48:1214-1219

Beckers A (2017) Legalization under the premises of globalization: why and where to enforce corporate social responsibility codes. Indiana J Glob Leg Stud 15:15-43

Beckert S (2014) Empire of cotton. A new history of global capitalism. Penguin, London

Brand U, Wissen M (2017) Imperiale Lebensweise. Zur Ausbeutung von Mensch und Natur im globalen Kapitalismus. Oekom, München

Britton-Purdy $\mathbf{J}$ et al (2020) Building a law-and-political-economy framework: beyond the twentieth-century synthesis. Yale Law J 129:1784-1832

Brown W (2000) Suffering rights as paradoxes. Constellations 7(2):230-241

Buckel S (2009) Zwischen Schutz und Maskerade - Kritik(en) des Rechts. RAV Infobrief 102:11-23

Buckel S (2015) Subjektivierung und Kohäsion. Velbrück, Weilerswist-Metternich

Butler J (1991) Unbehagen der Geschlechter. Suhrkamp, Frankfurt am Main

Butler J (2006) Haß spricht - Zur Politik des Performativen. Suhrkamp, Frankfurt am Main

Chimni BS (2013) Critical theory and international economic law: a third world approach to international law (TWAIL) perspective. In: Linarelli J (ed) Research handbook on global justice and international economic law, pp 251-273

Clean Clothes Campaign (2005) Looking for a quick fix - how weak social auditing is keeping workers in sweatshops. Amsterdam

Duffy H (2018) Strategic human rights litigation: understanding and maximising impact. Bloomsbury, Oxford

Gabel P, Harris P (1982-1983) Building power and breaking images: critical legal theory and the practice of law. Rev Law Soc Change 11:369-411

Gathii J, Odumosu-Ayanu I (2015) The turn to contractual responsibility in the global extractive industry. Bus Hum Rights J 1(1):69-94 
Geistfeld M (2019) The law and economics of tort liability for human rights violations in global supply chains. J Eur Tort Law 10(2):130-165

Gereffi G, Humphrey J, Sturgeon T (2005) The governance of global value chains. Rev Int Polit Econ 12:78-104

Glinski C, Rott P (2019) Regulating certification bodies in the field of medical devices: the PIP breast implants litigation and beyond. Eur Rev Private Law 27(2):403-428

Habersack M, Ehrl M (2019) Verantwortlichkeit inländischer Unternehmen für Menschenrechtsverletzungen durch ausländische Zulieferer - de lege lata und de lege ferenda. Archiv für die civilistische Praxis 219(2):155-210

Haider K (2019) Haftung von transnationalen Unternehmen und Staaten für Menschenrechtsverletzungen. Nomos, Baden-Baden

Heinen A (2018) Auf dem Weg zu einem transnationalen Deliktsrecht? - Zur Begründung deliktischer Sorgfalts- und Organisationspflichten in globalen Wertschöpfungsketten. In: Krajewski M, Saage-Maaß M (eds) Durchsetzung menschenrechtlicher Sorgfaltspflichten von Unternehmen. Nomos, Baden-Baden, pp 87-124

Heinlein I (2018) Zivilrechtliche Verantwortung transnationaler Unternehmenfür sichere und gesunde Arbeitsbedingungen in den Betrieben ihrer Lieferanten. Neue Zeitschrift für Arbeitsrecht 2018:276-282

Hoffman B, Vahlsin M (2014) Collaborative lawyering in transnational human rights advocacy. Clin Law Rev 21:255-282

Horst J (2015) Lex Financiaria. Das transnationale Finanzmarktrecht der International Swaps and Derivatives Association (ISDA). Archiv des Völkerrechts 53:461-500

Horst J (2019) Transnationale Rechtserzeugung. Elemente einer normativen Theorie der Lex Financiaria. Mohr-Siebeck, Tübingen

Hossain (2012) Exprts, equity, and empowerment: The Effects of readymade garments manufacturing employment on gender equality in angladesh. World Development Report

Kaleck W, Saage-Maaß M (2010) Corporate accountability for human rights violations amounting to international crimes. J Int Crim Just 8:699-724

Kaleck W, Saage-Maaß M (2016) Unternehmen vor Gericht. Wagenbach, Berlin

Kennedy D (1997) A critique of adjudication. Harvard University Press, Cambridge

Kirchheimer O (1976) Reichsgericht und Enteignung: Reichsverfassungswidrigkeit des Preußischen Fluchtliniengesetzes? In: Kirchheimer O, Luthardt W (eds) Von der Weimarer Republik zum Faschismus: Die Auflösung der demokratischen Rechtsordnung. Suhrkamp, Frankfurt am Main, pp 77-90

Klein N (2005) No Logo. Der Kampf der Global Players um die Marktmacht. Riemann, München

Knuckey $\mathrm{S}$ et al (2020) Power in human rights advocate and rightsholder relationships: critiques, reforms, and challenges. Harv Hum Rights J 33:101-155

König C (2017) Deliktshaftung von Konzernmuttergesellschaften. Archiv für die civilistische Praxis 217(4-5):611-686

Krajewski M, Bozorgzad M, Heß R (2016) Menschenrechtliche Pflichten von multi-nationalen Unternehmen in den OECD-Leitsätzen: taking human rights more seriously? Zeitschrift für ausländisches öffentliches Recht und Völkerrecht 76:309-340

Kumar (2015) Conditions of paraquat use in India. http://www.pan-india.org/wp-content/uploads/ 2017/03/BD_paraquat_4-15_def-WEB.pdf Accessed 12 April 2021

Lehmann U (2012) Mode gegen Moderne. In: Rohr et al (eds) Mode: Ein Kulturwissenschaflicher Grundriss. Wilhelm Fink, Munich, pp 23-55

Lessenich S (2018) Neben uns die Sintflut. Wie wir auf Kosten anderer leben. Piper, Munich

Lobel J (2003) Success without victory. New York University Press, New York

Locke R, Qin F, Brause A (2006) Does monitoring improve labour standards? Lessons from Nike. MIT Sloan Research Paper 4612(6)

Mansel HP (2018) Internationales Privatrecht de lege lata wie de lege ferenda und Menschenrechtsverantwortlichkeit deutscher Unternehmen. Zeitschrift für Unternehmens- und Gesellschaftsrecht 47(2-3):439-478 
Marshall AM, Hale DC (2014) Cause lawyering. Annu Rev Law Soc Sci 10(1):301-320

McCann M (2008) Litigation and legal mobilization. In: Whittington KE, Kelemen RD, Caldeira GA (eds) The Oxford handbook of law and politics. Oxford University Press, Oxford

Meeran R (2011) Tort litigation against multi-national corporations. City Univ Hong Kong Law Rev 3:1-41

Menke C (2018a) Kritik der Rechte. Suhrkamp, Berlin

Menke C (2018b) Genealogie, Paradoxie, Transformation. Grundelemente einer Kritik der Rechte. In: Fischer-Lescano A, Franzki H, Horst J (eds) Gegenrechte. Recht jenseits des Subjekts. Mohr-Siebeck, Tübingen, pp 13-31

Mgbeoji I (2006) Global biopiracy: patents, plants, and indigenous knowledge. Cornell University Press, Ithaca

Möller K, Raimondi F (2015) Mensch, institution, revolution. Zur Politik der Menschenrechte. Forschungsjournal Soziale Bewegungen 28(4):38-46

Müller U (2019) Begriffe, Ansprüche und deren Wirklichkeiten. Zeitschrift für Rechtssoziologie 39 (19):33-63

Neumann F (1980) Die Herrschaft des Gesetzes. Suhrkamp, Frankfurt am Main

Nordhues S (2019) Die Haftung der Muttergesellschaft und ihres Vorstandes für Menschenrechtsverletzungen im Konzern. Nomos, Baden-Baden

Nova and Zeldenrust (2020) Who will bail out the workers that make our clothes? Workers' rights consortium white paper, Washington D.C.

Orsenna E (2007) Weisse Plantagen. Eine Reise durch unsere globalisierte Welt. C.H. Beck, Munich

Osieka G (2014) Zivilrechtliche Haftung deutscher Unternehmen für menschenrechtsbeeinträchtigende Handlungen ihrer Zulieferer. Peter Lang, Frankfurt am Main

Pistor K (2019) Code of capital. How the law creates wealth and inequality. Princeton University Press, Princeton

Plank et al. (2009) Labour rights in global production networks. An qnalysis of the apparel and electronics sector in romania, Vienna

Rahmatian A (2009) Neo-colonial aspects of global intellectual property protection. J World Intellect Prop 12(1):40-74

Saage-Maaß M (2014) Holding corporations accountable: lessons from transnational human rights litigation. In: ECCHR, Brot für die Welt and Misereor (eds), Berlin

Saage-Maaß M (2021) Tort law litigation in germany. In: Richard Meeran (eds), Human rights litigation against multinationals in practice, Oxford University Press, Oxford

Schall A (2018) Die Mutter-Verantwortlichkeit für Menschenrechtsverletzungen ihrer Auslandstöchter. Zeitschrift für Unternehmens- und Gesellschaftsrecht 47(2-3):479-512

Segger S (2018) Europäisches Haftungsmodell für Menschenrechtsverletzungen von Unternehmen? In: Krajewski M, Saage-Maaß M (eds) Die Durchsetzung menschenrechtlicher Sorgfaltspflichten von Unternehmen. Zivilrechtliche Haftung und Berichterstattung als Steuerungsinstrumente. Nomos, Baden Baden, pp 21-60

Spitzer M (2019) Human rights, global supply chains, and the role of tort. J Eur Tort Law 10 (2):95-107

Sumon M, Shifa N, Gulrukh S (2017) Discourses of compensation and the normalization of negligence: the experience of the Tazreen factory fire. In: Prentice R, De Neve G (eds) Unmaking the global sweatshop: health and safety of the world's garment workers. University of Pennsylvania Press, Pennsylvania, pp 47-172

Terwindt C et al (2018) Supply chain liability: pushing the boundaries of the common law? J Eur Tort Law 8(3):261-296

Thiede T, Bell A (2017) Klagen clever kaufen! Zur Haftung einer deutschen Textilhändlerin für die Opfer eines Brandes in der Fabrik eines pakistanischen Zuliefererbetriebs. Recht der Internationalen Wirtschaft 5:263-272

Thomale C, Hübner L (2017) Zivilgerichtliche Durchsetzung völkerrechtlicher Unternehmensverantwortung. Juristenzeitung 72(8):385-397 
Van Dam C (2010) Tort law and human rights: brothers in arms on the role of tortlaw in the area of business and human rights. J Eur Tort Law 3:221-254

Vogt et al (2020) Farce majeure: How global apparel brands are using the COVID-19 pandemic to stiff suppliers and abandon workers, Policy Paper, https://www.ecchr.eu/en/publication/dieausrede-der-hoeheren-gewalt/. Accessed 12 April 2021

Von Falkenhausen (2020) Menschenrechtsschutz durch deliktsrecht. Unternehmerische pflichten in internationalen lieferketten, Mohr Siebeck, Tübingen

Wagner G (2016) Haftung für Menschenrechtsverletzungen. Rabels Zeitschrift für ausländisches und internationals Privatrecht 80:717-782

Wagner G (2017) § 823. In: von Hein J (ed) Münchener Kommentar zum Bürgerlichen Gesetzbuch, vol 7

Weller MP, Thomale C (2017) Menschenrechtsklagen gegen deutsche Unternehmen. Zeitschrift für Unternehmens- und Gesellschaftsrecht 46(4):509-526

Weller MP, Kaller L, Schulz A (2016) Haftung deutscher Unternehmen für Menschenrechtsverletzungen im Ausland. Archiv für die civilistische Praxis 216(3-4):387-420

Wendelstein C (2019) Menschenrechtliche Verhaltenspflichten im System des Internationalen Privatrechts. Rabels Zeitschrift für ausländisches und internationals Privatrecht 83(1):111-153 Williams P (1987) Alchemical notes: reconstructing ideals from deconstructed rights. Harv Civil Rights Civil Liberties Law Rev 40(22):401-433

Yusuf H (2010) Pakistan's anti-terrorism courts. CTS Sentinel 3(3):22-25

Miriam Saage-Maaß is a lawyer and vice legal director at ECCHR, where she has developed and since several years heads the Business and Human Rights program. She worked on various cases against corporations, including civil proceedings against German retailers regarding labor exploitation in South Asia. Furthermore, she is engaged in criminal proceedings against high-ranking managers for their involvement in international crimes, e.g. arms exports from Europe to Saudi Arabia. She regularly publishes articles on the question of corporate accountability for human rights violations in global supply chains and is an internationally renowned expert for corporate responsibility and human rights. She lectures at Freie Universität Berlin, Germany, and joined the Board of the Bonavero Institute for Human Rights at Oxford University in 2018 and the Stiftung Forum Recht's advisory board in 2020.

Open Access This chapter is licensed under the terms of the Creative Commons Attribution 4.0 International License (http://creativecommons.org/licenses/by/4.0/), which permits use, sharing, adaptation, distribution and reproduction in any medium or format, as long as you give appropriate credit to the original author(s) and the source, provide a link to the Creative Commons license and indicate if changes were made.

The images or other third party material in this chapter are included in the chapter's Creative Commons license, unless indicated otherwise in a credit line to the material. If material is not included in the chapter's Creative Commons license and your intended use is not permitted by statutory regulation or exceeds the permitted use, you will need to obtain permission directly from the copyright holder.

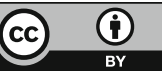

